\title{
STRATEGI PENGELOLAAN AGROFORESTRI BERBASIS AREN DI PULAU BACAN KABUPATEN HALMAHERA SELATAN
}

\author{
Mahdi Tamrin $^{1 *}$, Leti Sundawati ${ }^{2}$, Nurheni Wijayanto ${ }^{3}$ \\ ${ }^{1}$ Program Studi Ilmu Pengelolaan Hutan \\ Sekolah Pascasarjana Institut Pertanian Bogor (IPB), Bogor 16680 \\ *E-Mail: adhy.nagkokotu@gmail.com \\ ${ }^{2}$ Departemen Manajemen Hutan, Fakultas Kehutanan IPB, Bogor 16680 \\ ${ }^{3}$ Departemen Silvikultur Tropika, Fakultas Kehutanan IPB, Bogor 16680
}

\begin{abstract}
RINGKASAN
Agroforestri merupakan bentuk pemanfaatan lahan yang dikembangkan untuk memberikan manfaat ekonomi, ekologi dan sosial. Selain itu agroforestri memiliki peran untuk meningkatkan kesejahteraan masyarakat dengan menjamin ketersediaan pangan yang cukup dan mampu berperan sebagai penyedia bahan baku untuk bahan bakar nabati dan fungsi ekologis bagi masyarakat. Sistem penggunaan lahan agroforestri di Propinsi Maluku Utara mencampurkan banyak jenis tanaman, diantaranya adalah aren (Arenga pinnata Merr) sebagai tanaman utama. Salah satu sentra agroforestri berbasis aren adalah Kabupaten Halmahera Selatan. Penelitian ini dilaksanakan di Desa Kampung Makian, Kecamatan Bacan Selatan, Kabupaten Halmahera Selatan. Hasil penelitian menunjukan bahwa pengelolaan agroforestri berbasis aren dapat memberi kontribusi sebesar 99.29\% terhadap pendapatan rumah tangga desa Kampung Makian. Agroforestri berbasis aren di Kabupaten Halmahera Selatan dapat dikembangakan dengan melakukan deversifikasi produk dan perluasan pasar hasil-hasil agroforestri.
\end{abstract}

Kata Kunci: agroforestri, aren, strategi pengelolaan, Halmahera Selatan

\section{PERNYATAAN KUNCI}

- Pengelolaan agroforestri aren di Desa Kampung Makian masih sangat tradisional yang dilakukan secara turun temurun sampai saat ini oleh petani. Proses pengelolaan dengan pemanfaatan nira menjadi gula aren dilakukan sebagai industri rumah tangga (bome industry) dan secara berkelanjutan (sustainable) dengan menggunakan teknologi sederhana. Hal ini menjadi tabungan bagi rumah tangga pengelola aren karena produktifitas aren dan pemanfaatan dilakukan secara tidak berlebihan.

- Pengelolaan agroforestri dengan pola sederhana yang digunakan petani Desa Kampung Makian memberikan kontribusi 99.29\% terhadap pendapatan petani dan masih dapat dikembangkan.

- Konversi lahan merupakan masalah yang krusial. Fenomena alih fungsi lahan pertanian dan perkebunan ke pembangunan fisik seperti perkantoran dan perumahan serta adanya 
perluasan perkotaan di desa Kampung Makian merupakan ancaman serius bagi petani setempat. Adanya ancaman ini karena dampak transformasi struktur ekonomi, sosial, dan demografis yang mengakibatkan penggunaan lahan bergeser pada aktivitas non pertanian.

\section{REKOMENDASI KEBIJAKAN}

- Pengelolaan agroforestri berbasis aren di desa Kampung Makian menghadapi situasi ancaman, maka perlu merancang dan menerapkan strategi dengan menggunakan kekuatan dari segi internal untuk memanfaatkan peluang jangka panjang dengan cara melakukan strategi diversifikasi produk hasil agroforestri.

- Hasil penelitian ini memberikan informasi bahwa saat ini kelompok tani yang dibentuk bersifat situasional. Kelompok tani ini dipersiapkan untuk menjemput berbagai program pemerintah dibidang pertanian dan perkebunan yang bersifat sementara, secara kelembagaan kelompok tani ini lemah karena tidak memiliki struktur organisasi maupun program organisasi. Oleh karena itu, perlu dibentuk kelompok tani secara permanen guna mengoptimalkan kemampuan petani dalam melakukan seluruh aspek pengelolaan agroforestri seperti pembibitan, penanaman, pemeliharaan, pemanenan, dan pemasaran.

\section{PENDAHULUAN}

Sistem agroforestri merupakan bentuk pemanfaatan lahan yang dikembangkan untuk memberikan manfaat ekonomi, ekologi dan sosial sehingga dapat meningkatkan kesejahteraan masyarakat. Selain memiliki peran untuk meningkatkan kesejahteraan masyarakat agroforestri juga menjamin ketersediaan pangan yang cukup dan mampu berperan sebagai penyedia bahan baku untuk bahan bakar nabati dan fungsi ekologis bagi masyarakat (Rivaie 2015). Tujuan yang diharapkan dari pengolahan lahan dengan sistem agroforestri untuk mempertahankan jumlah dan keragaman produksi lahan (Indriyanto 2008; Simatupang 2011; Qurniati et al. 2013; Fauziah et al. 2013). Sistem ini dapat menggantikan fungsi ekosistem hutan sebagai pengatur siklus hara dan berpengaruh positif terhadap lingkungan lainnya serta dapat diandalkan untuk memproduksi hasil-hasil pertanian sesuai dengan agroklimat setempat (Suprayogo et al. 2003).

Pulau-pulau kecil didefinisikan sebagai pulau dengan luas area kurang dari atau sama dengan $2.000 \mathrm{~km}^{2}$ (Undang-undang No. 1 tahun 2014), merupakan wilayah dengan karakteristik yang khas, yaitu luasan daratannya yang kecil, relatif jauh dari daratan induk (mainland), relatif peka dalam konteks ekonomi maupun lingkungan biofisiknya (Adrinto 2005). Pulau-pulau kecil memiliki kerentanan yang tinggi terhadap perubahan lingkungan dan dampak perubahan iklim dan bencana alam, seperti tsunami, badai dan gelombang ekstrim, naiknya paras muka laut, dan gempa bumi. Namun demikian, pulu-pulau kecil cenderung memiliki jenis-jenis endemik dan keanekaragaman hayati laut yang tinggi, seperti ekosistem terumbu karang, ikan karang dan ekosistem mangrove (Adrianto 2005; Bengen dan Retraubun 2006).

Mengacu pada UU No. 1 tahun 2014 diatas, maka Kabupaten Halmahera Selatan yang terdiri dari tujuh pulau diantaranya Pulau Obi, Pulau Bacan, Pulau Makian, Pulau Kayoa, Pulau 
Kasiruta, Pulau Mandioli dan sebagian Pulau Halmahera di bagian Selatan merupakan pulau kecil yang memiliki potensi kerawanan cukup besar, karena distribusi pasokan pangan melalui transportasi laut dan dapat terputus pada saat kerawanan cuaca yang terjadi secara tiba-tiba. Untuk itu, perlu disusun suatu strategi dan kemampuan produksi pangan di pulau-pulau kecil yang dapat menjamin ketersediaan pangan masyarakat setempat guna mengantisipasi kerawanan pangan akibat terhambatnya pasokan bahan makanan selama cuaca dan musim yang buruk.

Kabupaten Halmahera Selatan dengan penduduknya bertumpu pada pertanian dan perikanan (BPS 2011), memiliki potensi sumber daya genetik lokal yang tinggi untuk berbagai jenis tanaman pertanian dan perkebunan. Tanaman aren (Arenga pinnata Merr) merupakan salah satu sumber daya genetik di kawasan tropika. Tanaman ini tumbuh secara alami dan tersebar di berbagai pulau di setiap kecamatan, salah satunya di Kecamatan Bacan Selatan, Kabupaten Halmahera Selatan. Kacamatan Bacan Selatan merupakan daerah penyumbang terbesar hasil aren untuk pemenuhan kebutuhan produksi gula aren di Halmahera Selatan. Tanaman tersebut tersebar dalam bentuk kebun campuran atau agroforestri yang dikelola oleh petani dengan luas yang beragam. Namun hanya sebagian kecil hasilnya yang dimanfaatkan dengan tingkat diversifikasi produk yang masih terbatas.

Prospek pengembangan tanaman aren dengan sistem agroforestri menjadi ketertarikan tersendiri untuk diteliti. Hal ini didukung oleh hasil penelitian Polakitan dan Akuba (1993) serta Akuba (2004) yang menyatakan bahwa tanaman aren dapat dikembangkan dalam sistem agroforestri antara tanaman kehutanan dan tanaman pertanian. Berdasarkan uraian di atas, maka perlu adanya penelitian yang memberikan informasi untuk mengembangkan aren sebagai komoditi yang dikelola dengan pola agroforestri, yang melibatkan masyarakat yang menjaga pola tersebut di tengah perkembangan adaptasi pengelolaan modern.

\section{KONDISI TERKINI}

\section{- Pengelolaan Agroforestri Berbasis Aren}

Pada umumnya, lahan yang diusahakan oleh responden merupakan lahan milik yang dikelola secara sederhana. Lahan milik merupakan lahan yang telah sah menjadi hak milik seseorang yang bertanggung jawab atas pengelolaan lahan tersebut untuk diperoleh manfaatnya. Ditinjau dari asalnya, tanah milik dapat dibedakan menjadi dua macam yaitu tanah milik warisan keluarga dan tanah milik pemberian dari pihak lain. Dari hasil wawancara rata-rata responden memiliki tanah milik sendiri dari warisan keluarga yang dikelola. Dalam pengelolaan kebun agroforestri berbasis aren, petani lebih banyak menggunakan pengalaman yang diperoleh dari orang tua maupun hasil pertukaran antar petani. Pengelolaan kebun terbagi atas beberapa kegiatan seperti persiapan lahan, persiapan bibit, penanaman, pemeliharaan, pemanenan, pengolahan dan pemasaran.

\section{Pengolahan nira aren}

Pengolahan nira aren dilakukan dengan peralatan yang sangat sederhana, yaitu bambu (alat panen) sebagai penampung nira, kuali atau wajan sebagai alat untuk pemasakan, pengaduk dan tungku kayu bakar untuk pemanasan. Nira hasil sadapan pagi dan sore ditampung menggunakan kuali selama empat hari diatas tungku dengan panas yang relatif kecil, sambil menampung nira 
aren untuk selanjutnya dimasak. Lama pemasakan nira aren hingga dicetak adalah 3-4 jam dengan rata-rata jumlah produksi yang dihasilkan 150-200 butir atau sekitar 75-80 kg/ dengan frekuensi produksi 5 hari. Gula yang telah dimasak selanjutnya dicetak ke dalam cetakan yang terbuat dari tempurung kelapa, cetakan tersebut terlebih dahulu dibersihkan dengan menggunakan air kapur dan merendamnya dengan air bersih untuk memudahkan pelepasan gula aren nantinya, selanjutnya dikemas dengan daun pisang kering dan siap untuk di pasarkan.

\section{Pemasaran}

Pemasaran hasil agroforestri aren khusus untuk tanaman perkebunan, pertanian dan buah-buahan biasanya petani lansung membawa ke pasar untuk dijual. Untuk tanaman kehutanan seperti kenari dan afu dan pohon lainnya yang terdapat di dalam kebun tidak dijual oleh petani, mereka umumnya menggunakan kayu-kayu tersebut untuk dijadikan kayu bakar atau papan untuk membuat rumah panggung atau rumah kebun (dodaru). Sedangkan untuk pemasaran gula aren rata-rata petani menjualnya ke pengumpul lokal. Hal itu dilakukan karena petani terlebih dahulu mengambil/meminjam uang untuk kebutuhan rumah tangga. Secara umum saluran pemasaran gula aren di Desa Kampung Makian Kecamatan Bacan Selatan terdiri dari 4 pola saluran pemasaran sebagaimana Gambar 1.

\section{- Pendapatan Rumah Tangga}

Dalam membiayai kebutuhannya, petani memperoleh penghasilan atau pendapatan dari dua sumber yaitu agroforestri dan non agroforestri. Pendapatan agroforestri terdiri dari kehutanan khususnya gula aren, tanaman perkebunan, pertanian, dan buah-buahan. Sedangkan pendapatan non agroforestri bersumber dari jasa (ojek) dan gaji. Secara lengkap sumber pendapatan responden dari masing-masing komponen jenis tanaman dicantumkan pada Tabel1.

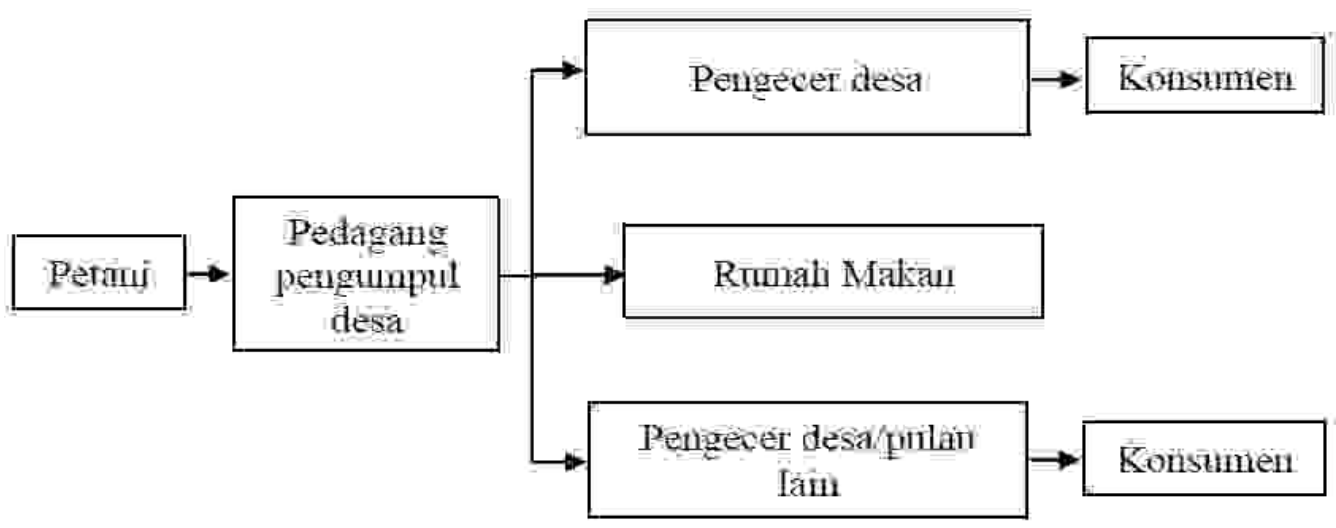

Gambar 1. Distribusi pemasaran gula aren

\section{Keterangan:}

Pola 1 : Petani-Pedagang Pengumpul lokal

Pola 2 : Petani-Pedagang Pengumpul lokal-Pengecer lokal- Konsumen

Pola 3 : Petani-Pedagang Pengumpul lokal-Rumah Makan

Pola 4 : Petani-Pedagang Pengumpul lokal-Pengecer Desa/Pulau Lain-Konsumen 
Tabel 1. Rata-rata pendapatan rumah tangga dari masing-masing sumber pendapatan

\begin{tabular}{|c|c|c|c|c|c|c|}
\hline \multirow{3}{*}{ No } & \multirow{3}{*}{$\begin{array}{l}\text { Sumber } \\
\text { pendapatan } \\
\text { (Rp/thn) }\end{array}$} & \multicolumn{3}{|c|}{ Strata } & \multirow{3}{*}{$\begin{array}{c}\text { Rata-rata } \\
\text { (Rp/thm) }\end{array}$} & \multirow{3}{*}{$\begin{array}{c}\text { Persentase } \\
\text { (\%) }\end{array}$} \\
\hline & & $\underline{I}$ & II & III & & \\
\hline & & Rp/thn & Rp/thn & Rp/thn & & \\
\hline A & Agroforestri & & & & & \\
\hline $\mathbf{I}$ & Aren & 37.446 .000 & 32.395 .000 & 32.520 .000 & 102361.000 & $98: 37$ \\
\hline 2 & Perkebunan & 459.600 & 137.000 & 18.560 & 615.160 & 0.59 \\
\hline 3 & Pertanian & 40000 & 40417 & $54=400$ & 134.817 & 012 \\
\hline 4 & Buah-buahan & 92600 & 45.000 & 27.440 & 165,040 & 0.15 \\
\hline B & Non Agroforestri & & & & & \\
\hline 1 & Ojek & 56,667 & 91667 & 0 & 148,333 & 0.14 \\
\hline 2 & Gaji & 0 & $a$ & 624.000 & 624,000 & 0.59 \\
\hline & Total & 38.094 .867 & 32.709083 & 33244400 & 104048350 & 100.00 \\
\hline
\end{tabular}

Berdasarkan Tabel 1 diatas diketahui bahwa rata-rata total pendapatan dari agroforestri maupun non agroforestri pada masing-masing komponen bervariasi. Pada komponen kehutanan khususnya gula aren memperoleh pendapatan sebesar Rp 102.361.000,-/thn dengan besar persentase $98.37 \%$, ini merupakan pendapatan terbesar pada komponen agroforestri. Selanjutnya komponen perkebunan memperoleh pendapatan sebesar Rp 615.160,-/thn atau 0.59\%, sedangkan komponen pertanian memperoleh pendapatan sebesar Rp 134.817,-/thn atau sebanyak 0.12\% dan komponen buah-buahan dengan besaran pendapatan Rp 165.040,-/thn dengan besar persentase $0.15 \%$ yang merupakan pendapatan paling rendah dibanding dua komponen diatas, hal ini dikarenakan petani tidak memprioritaskan tanaman ini sebagai sumber pendapatan utama sehingga pemeliharaannya tidak dilakukan secara intensif melainkan hanya dibiarkan tumbuh begitu saja. Sedangkan non agroforestri yang ber-sumber dari jasa ojek merupakan mata pencaharian sampingan oleh petani dengan memperoleh rata-rata pendapatan sebesar $\mathrm{Rp} 148.333,-/$ thn atau $0.41 \%$. Sedangkan pendapatan lain pada komponen non agroforestri adalah gaji dengan besar pendapatan Rp 624.000,- thn atau 0.59\%.

\section{- Kontribusi Pengelolaan Agroforestri Berbasis Aren}

Kondribusi pengelolaan agroforestri berbasis aren dihitung melalui pemanfaatan produk yang berasal dari tanaman kehutanan (gula aren), tanaman perkebunan (kakao, cengkeh) tanaman pertanian (cabe, tomat, terong), dan buah-buahan (pisang dan langsat) yang terdapat dalam kebun agroforestri yang dimanfaatkan petani secara langsung (Tabel 2).

Tabel 2. Distribusi pendapatan rata-rata responden per tahun berdasarkan stratifikasi pemilikan lahan

\begin{tabular}{lcccccc}
\hline \multicolumn{7}{c}{ Rata-rata pendapatan (RT/thn) } \\
\hline Strata & $\begin{array}{c}\text { Luas lahan } \\
\text { (Ha) }\end{array}$ & $\mathrm{N}$ & $\begin{array}{c}\text { Agroforestri } \\
(\mathrm{Rp} / \mathrm{thn})\end{array}$ & $\begin{array}{c}\text { Non } \\
\text { agroforestri } \\
\text { (Rp/thn) }\end{array}$ & $\begin{array}{c}\text { Total } \\
(\mathrm{Rp} / \mathrm{thn})\end{array}$ & $\begin{array}{c}\text { Kontribusi } \\
\text { agroforestri (\%) }\end{array}$ \\
\hline I & $>2$ & 30 & 38.038 .200 & 56.667 & 38.094 .867 & 99.86 \\
II & $1.5-2$ & 24 & 32.617 .417 & 91.667 & 32.709 .083 & 99.72 \\
III & $1-1.5$ & 25 & 32.620 .400 & 624.000 & 33.244 .400 & 98.13 \\
\hline \multicolumn{2}{l}{ Rata-rata } & 79 & 34.676 .886 & 246.835 & 34.923 .385 & 99.29 \\
\hline
\end{tabular}


Berdasarkan data pada Tabel 2 diatas diketahui bahwa pengelolaan agroforestri memiliki kontribusi terhadap pendapatan rumah tangga berdasarkan luas kepemilikan lahan. Pada strata I dengan luas lahan $>2$ ha memperoleh kontribusi sebesar $99.86 \%$ sedangkan pada strata II dengan luasan lahan $1.5-2$ ha yaitu $99.72 \%$ dan luasan lahan 1-1.5 ha pada strata III memperoleh kontribusi sebesar $98.13 \%$.

\section{ANALISIS DAN ALTERNATIF SOLUSI}

\section{- Strategi Pengelolaan Agroforestri}

\section{Berbasis Aren}

Strategi pada umumnya merupakan alat yang digunakan untuk mencapai tujuan (Chandler 1962 dalam Rangkuti 1997). Perumusan strategi pengelolaan agroforestri aren di desa Kampung Makian Kecamatan Bacan Selatan menghasilkan variabel yang dirangkum untuk mendapatkan alternatif strategi pengelolaan melalui matriks internal-eksternal. Uraian secara lengkap faktor internal dan faktor eksternal dapat dilihat di bawah ini :

\section{Faktor internal}

Analisis faktor internal pengelolaan agroforestri aren adalah langkah awal dalam merumuskan strategi pengelolaan, analisis ini dilakukan untuk mengidentifikasi faktor-faktor yang menjadi kekuatan dan kelemahan suatu usaha. Hasil identifikasi faktor kekuatan dan kelemahan yang dimiliki suatu usaha dapat digunakan sebagai dasar penetapan strategi pengelolaan dan pengembangan usaha sehingga peluang pasar dapat dimanfaatkan dengan baik (Rangkuti 1997). Identifikasi ke lokasi dengan melibatkan beberapa expert terpilih yang dianggap mengetahui tentang pengelolaan agroforestri, penilaian bobot dan rating faktor internal ditampilkan pada matriks faktor strategi internal.

Tabel 3. Faktor strategi internal

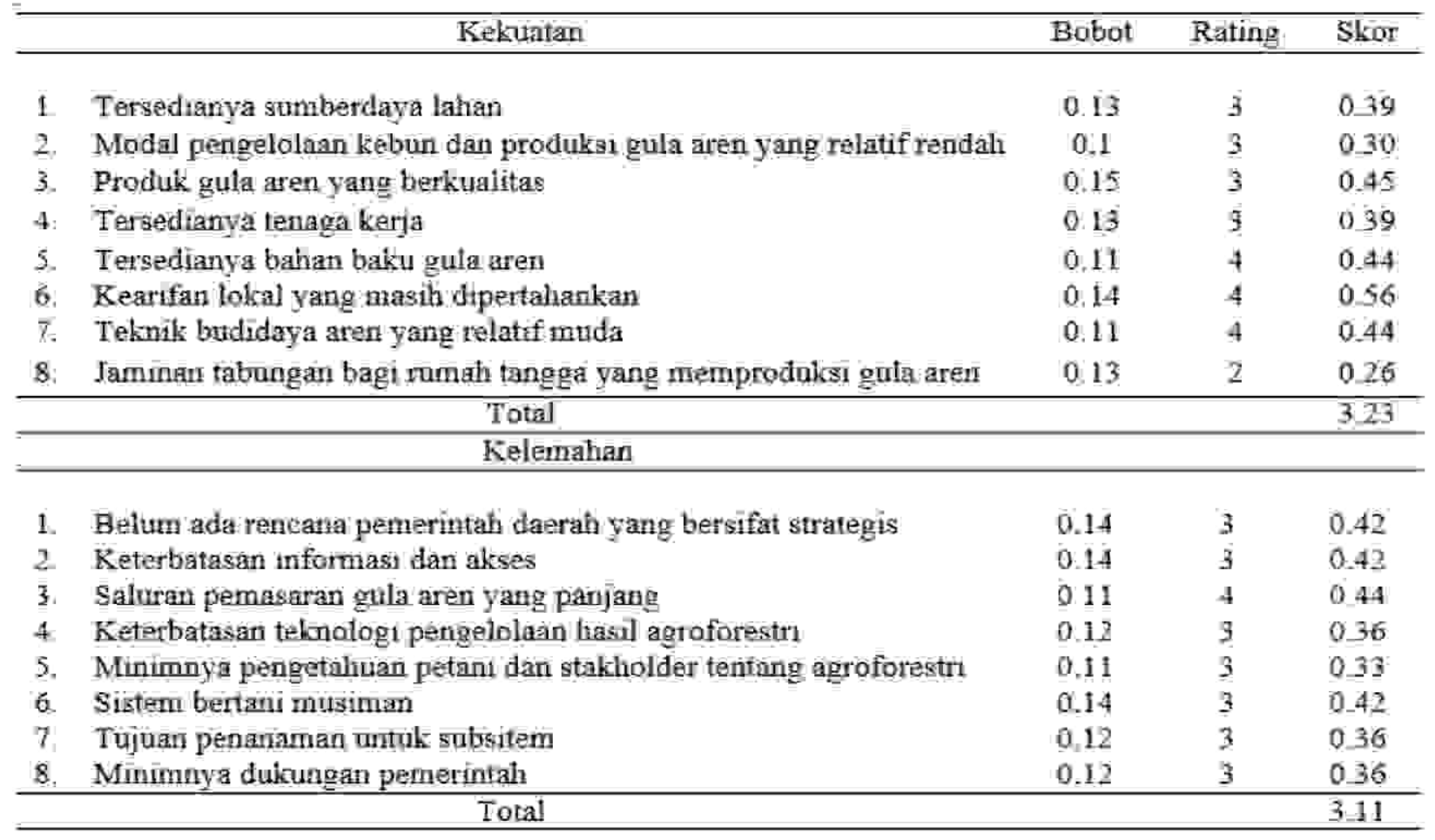




\section{Faktor eksternal}

Analisis faktor ekternal pengelolaan agroforestri berbasis aren ditujukan untuk mengidentifikasi faktor-faktor yang menjadi peluang dan ancaman yang dihadapi petani. Peluang merupakan suatu usaha yang dibangun/beroperasi secara menguntungkan sedangkan ancaman adalah tantangan yang timbul karena adanya perubahan lingkungan yang dapat mengurangi keuntungan suatu usaha. Identifikasi faktor eksternal dengan melibatkan beberapa expert terpilih dari stakeholder terkait yang dianggap mengetahui tentang pengelolaan agroforestri, penilaian bobot dan rating faktor eksternal ditampilkan pada matriks faktor strategi eksternal.

Pemilihan alternatif strategi yang sesuai dengan kondisi yang ada dengan membuat matriks SWOT. Matriks SWOT dibangun berdasarkan hasil analisis faktor-faktor strategis eksternal maupun internal yang disusun empat strategi utama yaitu: SO, WO, ST dan WT (Tabel 5). Berdasarkan hasil perhitungan skor pada matrik EFAS dan IFAS pengelolaan agroforestri berbasis aren desa Kampung Makian Kecamatan Bacan Selatan berada pada posisi kuadran II (0.12 ; -0.68). Kuadran II merupakan situasi petani dalam menghadapi ancaman, namun petani masih memiliki kekuatan dari segi internal yaitu strategi yang harus diterapkan dengan menggunakan kekuatan untuk memanfaatkan peluang jangka panjang dengan cara strategi diversifikasi produk. Posisi pengelolaan agroforestri berbasis aren di desa Kampung Makian Kecamatan Bacan Selatan dalam bentuk diagram analisis SWOT seperti pada Gambar 2.

Diagram SWOT dan Matrik SWOT) menggambarkan posisi pengelolaan agroforestri berbasis aren menghadapi situasi ancaman, maka perlu merancang dan menerapkan strategi dengan menggunakan kekuatan dari segi internal untuk memanfaatkan peluang jangka panjang dengan cara melakukan strategi diversifikasi produk hasil agroforestri di desa Kampung Makian.

Tabel 4. Strategi faktor eksternal

\begin{tabular}{|c|c|c|c|}
\hline Peluang & Bobot & Rating & Skor \\
\hline 1. Pendampingan petami oleh LSM & 0.18 & 3 & 0.54 \\
\hline 2 Terbukanya pakar antar kota/kabupaten antar pulau & 0.23 & 3 & 0.69 \\
\hline 3. Kerjasama dengan mitra rumah makan & 0.21 & 3 & 0.63 \\
\hline 4. Meningkatnya harga dan permintaan gula aren & 0.19 & 3 & 0.57 \\
\hline 5. Pengembalaan pada lokasi $A f f$ & 0.19 & 3 & 0.57 \\
\hline Total & & & 3,00 \\
\hline \multicolumn{4}{|l|}{ Ancaman } \\
\hline 1 Konversi lahan dan menjual tanah & 0.32 & 3 & 096 \\
\hline 2 Hama dan penyakit & 0.41 & 4 & 1.64 \\
\hline 3. Dibukanya usaha batu akik bacan yang lebih produktif & 0.27 & 4 & 1.08 \\
\hline Total & & & 3.68 \\
\hline
\end{tabular}




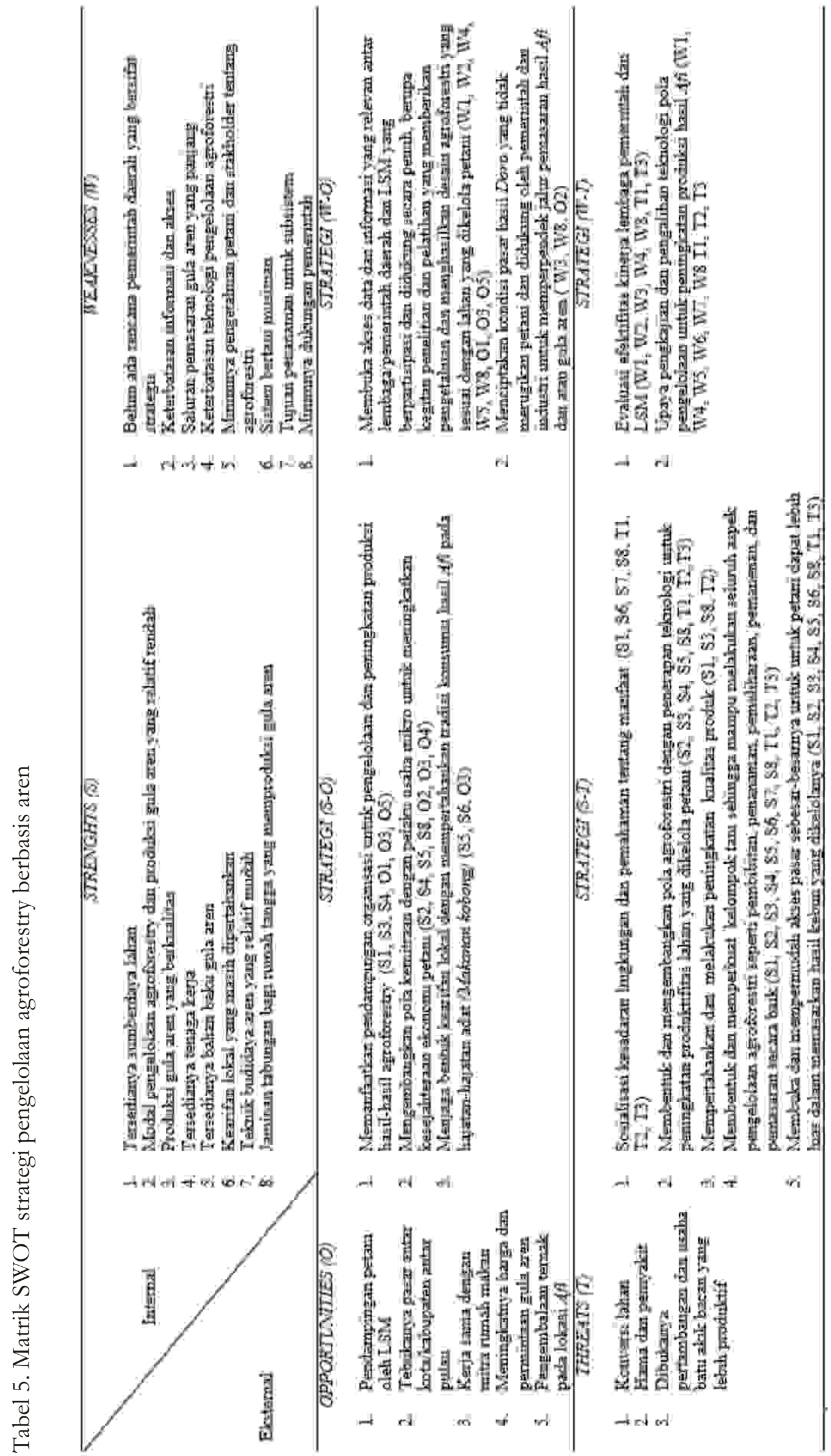




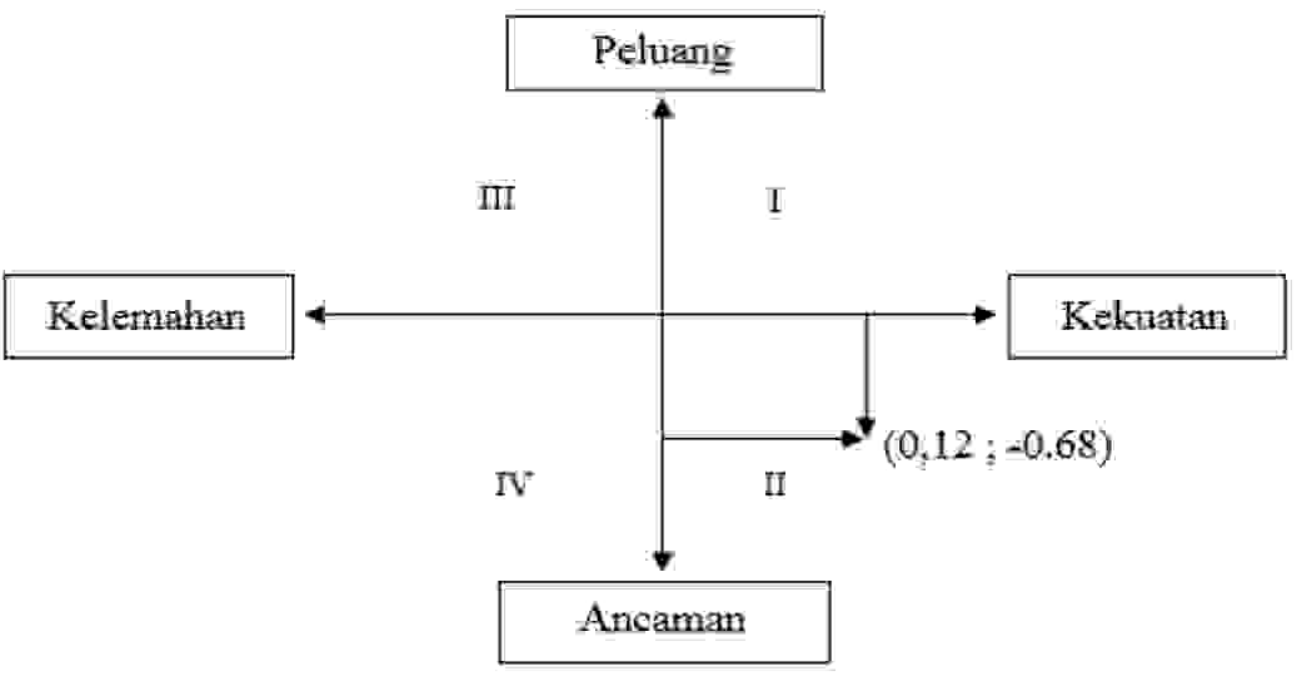

Gambar 2. Diagram analisis SWOT (posisi kuadran)

\section{- Strategi terpilih}

1. Sosialisasi kesadaran lingkungan dan pemahaman tentang manfaat Agroforestri (S1, S6, S7, S8, T1, T2, T3)

Masalah lingkungan merupakan suatu fenomena besar yang memerlukan perhatian khusus dari semua pihak. Untuk mewujudkan itu maka diperlukan berbagai cara, seperti sosialisai dan aksi nyata dengan melibatkan berbagai unsur. Terlepas dari sosialisali lingkungan, masyarakat perlu diberi pemahaman tentang manfaat agroforestri Afi. Agroforestri bertujuan untuk mempertahankan jumlah dan keragaman produksi lahan, sehingga dapat memberikan manfaat sosial, ekonomi dan lingkungan bagi para pengguna lahan (Indriyanto 2008).

2. Membentuk dan mengembangkan pola agroforestri dengan penerapan teknologi untuk peningkatan produktifitas lahan yang dikelola petani (S2, S3, S4, S5, S8, T1, T2,T3)

Berdasarkan hasil survei dan wawancara dilapangan bahwa pengelolaan agroforestri dengan pola sederhana yang digunakan petani desa Kampung Makian selama ini belum memberikan kontribusi besar terhadap pendapatan petani secara keseluruhan. Hal ini terlihat pada pola pemanfaatan lahan, masih banyak lahan produktif yang belum dimanfaatkan secara maksimal dari setiap lahan yang dimiliki petani. Untuk mewujudkan itu, maka perlu mengembangkan pola agroforestri moderen dengan penerapan terknologi untuk peningkatan profuktifitas lahan dan hasil-hasil pertnian dan perkebunan.

3. Mempertahankan dan melakukan peningkatan kualitas produk (S1, S3, S8, T2)

Kualitas gula aren yang dihasilkan petani sangat baik, hal ini terlihat pada proses pengolahan sampai pada pemasakan dan pengemasan dilakukan oleh petani sendiri, bahan campuran yang digunakan seperti pewarna, anti bakteri dan bahan penetralisir asam nira aren menggunakan bahan organik yang diambil dikebun-kebun petani. Namun perlu dilakukan peningkatan lebih dengan mendesain kemasan dan mengatur strategi pasar guna mengantisipasi persaingan pasar gula aren Kabupaten Halmahera Selatan dan Propinsi Maluku Utara secara umum.

4. Membentuk dan memperkuat kelompok tani sehingga mampu melakukan seluruh aspek 
pengelolaan agroforestri seperti pembibitan, penanaman, pemeliharaan, pemanenan, dan pemasaran secara baik (S1, S2, S3, S4, S5, S6, S7, S8, T1, T2, T3)

Hasil wawancara dilapangan menunjukan bahwa kelompok tani yang dibentuk bersifat situasional. Kelompok tani ini dipersiapkan untuk menjemput berbagai program pemerintah dibidang pertanian dan perkebunan yang bersifat sementara, secara kelembagaan kelompok tani ini lemah karena tidak memiliki struktur organisasi maupun program organisasi. Kartosapotra (1994) menyatakan bahwa kelompok tani terbentuk atas dasar kesadaran, jadi tidak secara terpaksa. Kelompok tani menghendaki terwujudnya pertanian yang baik, usahatani yang optimal dan keluarga tani yang sejahtera dalam perkembangan kehidupannya. Para anggota dibina agar berpandangan sama, berminat yang sama dan atas dasar kekeluargaan.

Pembentukan kelompok tani sangat diperlukan guna memperkuat kemampuan dasar petani dalam mengelola kebunnya, karena melalui kelompok tani, kemampuan petani dalam mengelola kebun akan terorganisir, pengusaan aspek pengelolaan akan menjadi lebih baik karena didampingi oleh pendamping yang memiliki kempuan dan pengelaman dibidang pertanian maupun perkebunan.

5. Membuka dan mempermudah akses pasar sebesar-besarnya untuk untuk petani dapat lebih luas dalam memasarkan hasil kebun yang dikelolanya (S1, S2, S3, S4, S5, S6, S8, T1, T3)

Alur pemasaran yang panjang membuat petani memilih jalur alternatif untuk menjual hasil produk ke pedagang pengumpul lokal dengan harga yang relatif kecil. Membuka peluang pasar untuk hasil agroforestri seperti gula aren merupakan hal mutlak yang harus dilakukan oleh pihak terkait guna mempermudah petani dalam menjual hasil-hasil produk agroforestri.

\section{REFERENSI}

Adrianto, L. 2005. Pembangunan dan Pengelolaan Pulau-Pulau Kecil yang Berkelanjutan (Sustainable Small Island Development and Management). Working Paper. Pusat Kajian Sumber Daya Pesisir dan Lautan, Institut Pertanian Bogor. Bogor. Indonesia.

Akuba, R.H. 2004. Profil Aren. Pengembangan Tanaman Aren. Prosiding Seminar Nasional Aren. Tondano. Balai Penelitian Tanaman Kelapa dan Palma Lain. 9 Juni.1 - 9.

Bengen, D.G., Retraubun, A. 2006. Menguak realitas dan urgensi pengelolaan berbasis eko-sosio sistem pulau-pulau kecil. Pusat Pembelajaran dan Pengembangan Pesisir dan Laut. Bogor.

[BPS] Badan Pusat Statistik Kabupaten Halmahera Selatan. 2011. Kabupaten Halmahera Selatan Dalam Angka 2011.

Indriyanto. 2008. Pengantar Budidaya Hutan. Jakarta (ID); Bumi Pustaka.

Kartosapotra, A.G. 1994. Teknologi Penyuluhan Pertanian. Jakarta (ID); Bumi Aksara

Nair, P.K.R. 1983. An Introduction to Agroforestry. Dordrecht/Boston/ London: Kluwer Academic Publishers.

Polakitan, A.L., Akuba, Akuba, R.H. 1993. Peluang Pengembangan Aren dalam Sistem Agroforestri dengan Pinus. Buletin Balitka (20): $73-80$.

Qurniati, R., Marlica, T.A., Haryono, D. 2013. Agroforestry Composition And Its Contribution Household Income In Pesawaran Indah Village District Pesawaran Lampung. Prosiding 
Penelitian-penelitian Agroforestri Di Simatupang, D.P. 2011. Kontribusi produk agroforestri Indonesia 1 (1):55- 64 terbadap pendapatan rumah tangga (Nagori Rangkuti, F. 1997. Analisis SWOT Teknik Membedah Kasus Bisnis, Reorientasi Simpang Raya Dasma, Kabupaten Simalungun). Prosiding Penelitian Agroforestri. Konsep Perencanaan Strategis Untuk Menghadapi Abad 21. Jakarta. PT Gramedia Pustaka Utama.

Rivaie, A.A. 2015. Potensi Penyediaan Pangan dan Konservasi Lahan Pulau-Pulau Kecil di Maluku: Peran Agroforestri Berbasis Aren. Jurnal Litbang Pertanian, 21(1): 173193.

Universitas Sumatra Utara. Medan.

Suprayogo, D., Hairiah, K., Wijayanto, N., Sunaryo., Noordwijk, M. 2003. Peran Agroforestri Pada Skala Plot: Analisis Komponen Agroforestri Sebagai Kunci Keberhasilan atau Kegagalan Pemanfaatan Lahan. Bogor: Word Agroforestri Center (ICRAF). Indonesia. 